\title{
VEHICLE IDENTIFICATION IN PARKING AREAS USING ADAPTIVE BRIGHTNESS THRESHOLDING
}

\section{IDENTIFIKASI KENDARAAN DI AREA PARKIR MENGGUNAKAN METODE AMBANG BATAS KECERAHAN YANG ADAPTIF}

\author{
Sahid Bismantoko ${ }^{a}$, M. Rosyidia ${ }^{a}$ Asep Haryono ${ }^{a}$, Tri Widodo ${ }^{a}$ \\ a Center of Technology for System and Infrastructure of Transportation \\ Agency for the Assessment and Application of Technology, Tangerang Selatan, Indonesia \\ e-mail: sahid.bismantoko@bppt.go.id, m.rosyidi@bppt.go.id, asep.haryono@bppt.go.id, \\ tri.widodo@bppt.go.id
}

\begin{abstract}
The problem of parking systems on the street is a classic problem that occurs from year to year, many solutions are offered in solving the parking problem on the street. The problem is not only related to traffic jams due to in and out of vehicles from the parking spaces but also the parking management issues become polemic at this time. A prototype of parking management monitoring system tries to provide solution in managing parking by using image processing based smart camera. In a prototype the system test performed on day and night conditions, to anticipate the very contrast difference intensity of pixels during the day or night so as to develop vehicle detection program using adaptive brightness thresholding. The results show that the program has been running quite well to identify vehicles during day and night timeframe.
\end{abstract}

Key Words: Image Processing; Deep Learning; CNN; VPN; Motorcycle; Smooth Traffic

\begin{abstract}
Abstrak
Permasalahan sistem parkir di jalan merupakan masalah klasik yang terjadi dari tahun ke tahun, khususnya terkait dengan keluar masuknya kendaraan, dan masih sedikitnya teknologi yang digunakan dalam pengelolaan parkir tersebut maka pengelolaan parkir menjadi tidak efisien yang dapat menyebabkan hambatan di jalan. Banyak solusi ditawarkan dalam menyelesaikan permasalahan ini, salah satunya adalah dengan memanfaatkan teknologi yang berbasis pada image processing. Penelitian ini fokus pada pengembangan teknologi identifikasi objek kendaraan dengan menggunakan smart camera. Hasil tangkapan kamera akan diproses oleh aplikasi identifikasi objek pada area parkir, smart camera tersebut diharapkan mampu mengidentifikasi kendaraan parkir serta memperkirakan jumlahnya. Pengujian sistem monitoring pengelolaan parkir di jalan dilakukan pada kondisi siang dan malam, untuk mengantisipasi perbedaan intensitas kontras pixel. Alasan inilah yang menyebabkan dikembangkannya sistem ini dengan pendekatan Adaptive Brightness Thresholding. Hasil pengujian menunjukkan bahwa program telah berjalan cukup baik untuk mengidentifikasi kendaraan pada siang dan malam hari.
\end{abstract}

Kata Kunci: Image Processing; Deep Learning; CNN; VPN; Motorcycle; Smooth Traffic

Diterima (received): 03 Februari 2020, Direvisi (revised): 17 Februari 2020,

Disetujui (accepted): 19 Februari 2020 


\section{INTRODUCTION}

Traffic congestion could become problem which is faced in urban area. Many factors can cause this problem, one of them is indiscipline in the use of parking areas that disturb the surrounding traffic. This problem can affect the optimization of the use parking space and disrupt traffic flow around the area.

In Indonesia has many roadside parking with parking attendant to conduct guide and pay fee parking transaction.

The image processing technology approach for solving parking problems can be done by processing image from Closedcircuit television camera to produce some information. However, the Light intensity will vary depending on environment condition.

This condition may bring up problem for identifying vehicle on parking areas at night or day, where the light intensity is different. The difference between light intensity in every pixel that can produce vary threshold value, so using adaptive thresholding may adjust the differences.

The Actual condition along roadside that are is only shuttle but do not park. One approach for solving this problem requires a verification method to determine whether the vehicle is parking or stopping by.

Castro et al. ${ }^{1)}$ conduct parking monitoring system development using camera based on image processing. The research focused on pixel intensity with adaptive thresholding with verification to verify vehicle status whether park or shuttle in parking area, this verification could be done to prevent error counting.

The purpose of this research is for verifying adaptive thresholding method in the parking management monitoring system on the roadside.

The stages of developing a prototype of a parking management monitoring system are as follows:

- Measuring light intensity

- Developing vehicle identification program

- Developing mobile and desktop application

- Testing the system

This research will be described in related research, the development of a prototype of a parking management monitoring system, as well as a trial run.

\section{RESEARCH METHODS}

Most of the smart parking research conducted, the research purpose to give information to the parking user by utilizing mobile application ${ }^{2-4}$. The other research focuses not only on information but reduce time consuming to seeking parking space ${ }^{5}$. Parking system that develop using visionbased by utilizing smart-camera system ${ }^{1-3,5)}$ and used to detect in and out of the vehicle at parking $\mathrm{area}^{3}$. Another research using vehicle body for vision-based target ${ }^{3,5}$ or plat number ${ }^{6,7)}$.

Ahmed et al. ${ }^{8)}$ conduct research about parking management system that has been integrated by combining one parking area with another parking area using Internet of Thing (IoT) technology. Research of parking management system has been conducted using different approaches, such as using combination image processing and camerabased. This system aims to support intelligence transportation system; managing and controlling, developing mobile application providing available parking spaces information, and developing inexpensive hardware related to the parking system $^{3,9,10)}$.

\section{PROTOTYPE DEVELOPMENT FOR MONITORING AND PARKING MANAGEMENT SYSTEM}

The research about monitoring and managing parking on road due to the problems of parking management and congestion that occurs near the parking area. The root of the problem is non-optimal utilization of the parking space. This research focus on development of smartcamera system based-on image processing technique, integrated with database to monitor vehicle in and out. Smart camera that detect vehicle during parking operational time, from morning to night.

The important step to develop this research:

- Develop monitoring and parking management system using vision-based camera sensors, optimize the processing using adaptive thresholding.

- Adaptive thresholding use to reduce the differences contrast of pixel intensity during the day or night time setting.

- Verification method are needed to give a confidence about the vehicle that has status stop at parking area or just stay for a moment, refer as shuttle. 
- Real experimental area, parking area on the roadway.

- The system integrated with database parking system.

Figure 1 show the architecture of prototype monitoring and parking management system. Vehicle capturing process inside parking area will be verified as vehicle that do the parking or shuttle, before sending the information of the true vehicle parking to the server.

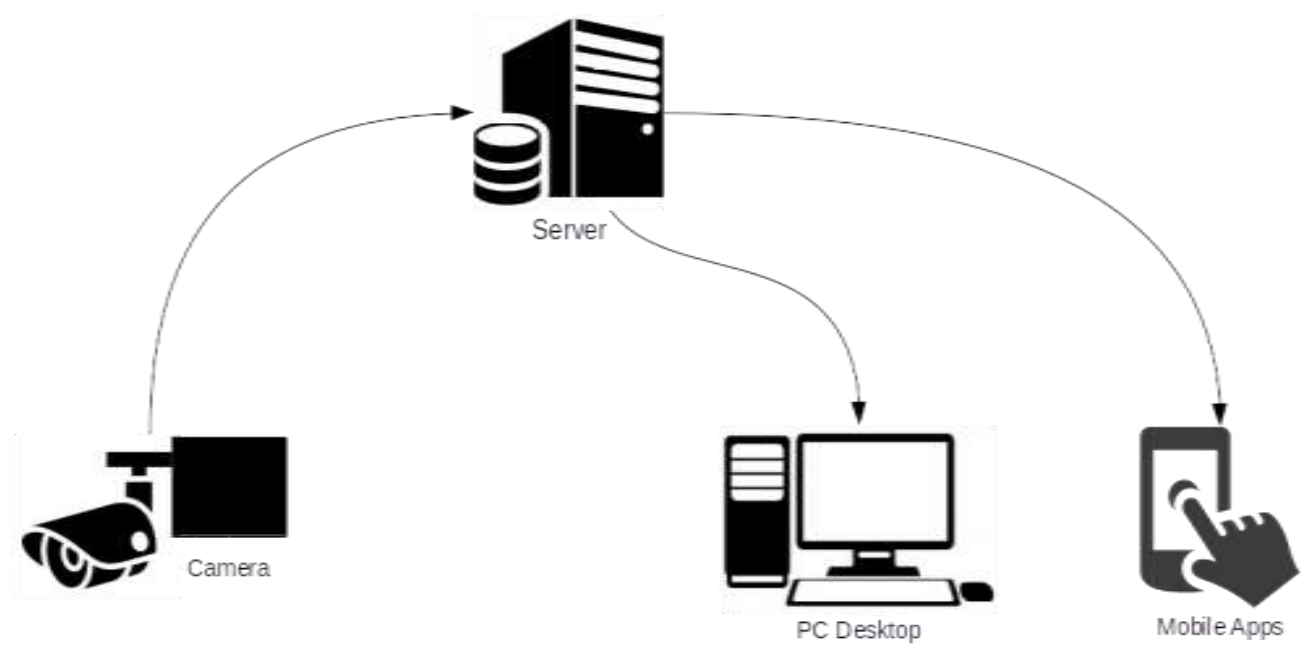

Figure 1.

The design of monitoring and management parking system on the road
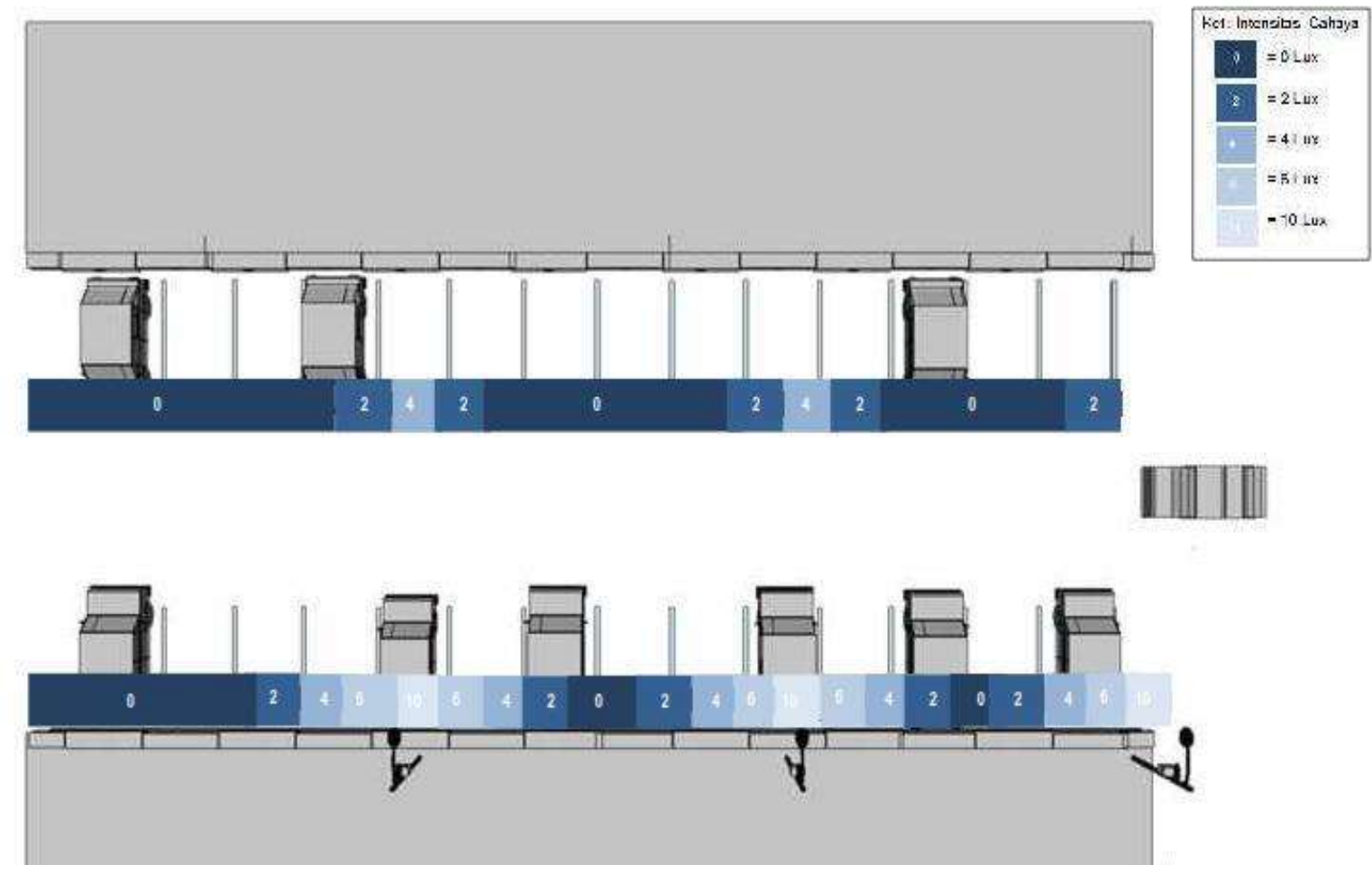

Figure 2.

The results of measurements of light intensity in the parking area on roadside park 
General step for data flow of the system show in the figure 1, are explain:

- Object that detected by camera will be process and verified as vehicle that do the parking or shuttle.

- Sending data to the server.

- Processing data as an information and represent the result to the website.

- Another process is loading the information to the mobile app.

\section{- Light intensity measurement}

Light intensity measurement in the parking area is an effort to find out the amount of light illumination in the parking area.

This measurement is needed to find out how much the light intensity in the parking area can be captured as a vehicle object by cameras so that it can be used as a threshold in the measurement.

The results of measurements, obtained the distribution of different light intensities, the light intensity will decrease with the change in distance or farther away from the light source.

Based on experiments that have been carried out, the results obtained as in the Figure 2

Table 1.

Illumination level based on colour in parking area

\begin{tabular}{|c|c|c|c|c|c|}
\hline Colour & & & & & \\
\hline Level & 0 & 2 & 4 & 6 & 10 \\
\hline
\end{tabular}

In Figure 2 shows that the linear ratio between the light source and the light intensity. The further from light source are getting less light intensity.

The value of the light intensity that will be used as a camera reference to capture images that can be identified as objects.

\section{- Vehicle Identification Programs Development}

The development of vehicle identification based on image processing has done a lot of research, in this study what distinguishes it from previous research as follow:

1. The program was developed so that it can function in day and night conditions, so that differences in contrast intensity of the pixel are tried to be adapted using adaptive thresholding.

2. Verification method to ensure that the vehicle is properly parked or only shuttle, so that it does not count as data.

The software used in this development are as follows:

* Main program $\mathrm{C}++$

* OpenCV

\section{- Adaptive Thresholding}

Adaptive thresholding is a technique for determining adaptive threshold values that can change according to conditions, this occurs when there are differences in contrasting illumination in an object.

The difference in the value of the adjacent pixel illumination is large so that it is difficult to uniform the value of the tenement into one value, so this is called local adaptive thresholding.

The method used to determine the local adaptive threshold value by using the average value of the threshold value, to get the value by segmenting objects, so that each sub-object will have their respective threshold values.

Because the threshold value for each pixel depends on the location of the pixels in the sub object. To get the optimal threshold value by using assumptions and statistical calculations as in the equation 1 :

$$
T=\frac{\mu_{1}+\mu_{2}}{2}
$$

$T$ refers to the threshold; $\mu 1$ is the average minimum pixel intensity; $\mu 2$ is the average maximum pixel intensity.

An empirical calculation of the adaptive threshold value is obtained as in the equation 2:

$$
T_{c}=\left(\frac{\mu_{1}+\mu_{2}}{2}\right)-\left(F\left(\frac{\mu_{1}+\mu_{2}}{2}\right)\right)
$$

Adaptive thresholding obtained empirically, $\mu 1$ and $\mu 2$ : minimum pixel intensity and maximum pixel intensity, and $F$ is a large value $(0.5-0.6)$.

\section{- Verification Method}

The verification method is an attempt to ascertain whether the parked vehicle is a parked vehicle or shuttle. This verification is required because the parking areas on the road are open. Verification method is done 
by setting the time delay of vehicle objects in the program, if the vehicle stops more than 15 seconds means the vehicle is parked and if less than 15 seconds means the vehicle is not parked.

\section{- Flowchart Development Program}

The development of object identification programs is built using the $\mathrm{C}++$ programming language with support.

Detailed description of program development can be explained as follows:

a) Make ROI (Rectangle of Interest) and blurring in that area, based on values in the configuration file.

b) Calculates the Laplacian value from the blurred ROI value, with the function in OpenCV cv:: Laplacian.

c) Calculate the delta by the difference between the mean value resulting from Laplacian calculations with the ROI masking value.

d) Retrieves the used parking status value.

e) Determine threshold value, threshold value dynamically changes depend on situation.



Figure 3.

Flowchart Vehicle Identification Program f) If the delta value is smaller than the threshold value in the config.cfg configuration file, then there is no object.

g) If no object exists and if the parking status is used as true then the delay function is executed for the change to false status.

h) If there is no object and if the parking status is used equal to true then the status remains true.

i) If the delta value is greater than the threshold value in the config.cfg configuration file, then there is an object.

j) If an object exists and if the parking status is used as true then the delay function is executed for the change to false status.

k) If there is an object and if the parking status is used the same as false, then the status remains false

Flowchart described on Figure 3 as follows: 


\section{DEVELOPMENT OF PARKING \\ MANAGEMENT MONITORING INFORMATION SYSTEM}

Parking management monitoring information system was developed to provide information to users and facilitate parking management. Information system architecture used as in figure 4.

Parking management monitoring information system architecture as shown in figure 4, the steps are explained as follows:

1) Desktop computer users access the web page by entering the URL address while mobile application users access the Android application which includes WebViewClient.

2) Web Server Software (Apache 2.0) will recognize a request from a PHP script file then the server will translate the file with a PHP plug-in before it is responded to by the page request.

3) PHP with the Yii Framework will connect to the MySQL database and request content that matches the web page.
4) The MySQL database will respond by sending content requested by the PHP script.

5) PHP scripts store content into one or several PHP variables and then an echo function will issue content according to what is on the web page.

6) PHP plug-in creates a copy of the HTML created by the Web server.

7) The web server sends an HTML to the Web browser / Web view that is written with an HTML file provided by PHP plug-in.

The software used in developing this information system includes:

1) Linux as an Operating System.

2) PHP 5 as a programming language

3) Yii 1.1.11 as Framework PHP.

4) MySQL database as Database Management System.

5) Netbeans IDE 8.1 as Integrated Development Environment.

6) Libreoffice Math 5.1.6.2 for conduct detailed flow diagrams.

7) Google maps API as Map View service to display maps.

8) Mozilla Firefox and Google Chrome as browsers to access the system.

9) Android Studio 2.3 as IDE android.

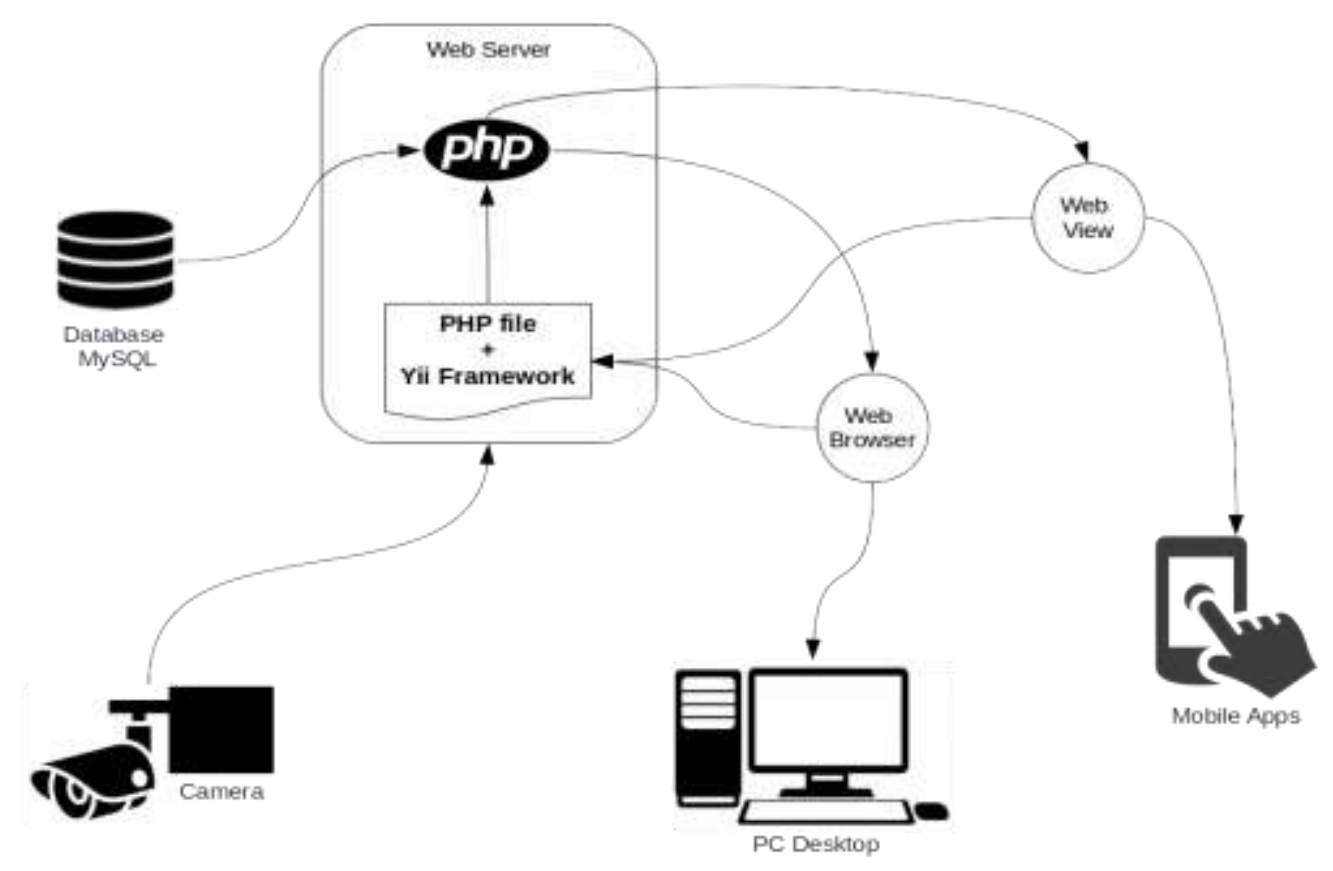

Figure 4.

Parking Monitoring System Architecture 


\section{TESTING}

The prototype test of the parking management monitoring system was carried out in the parking area, while the description of the parking area used was as in figure 5 .

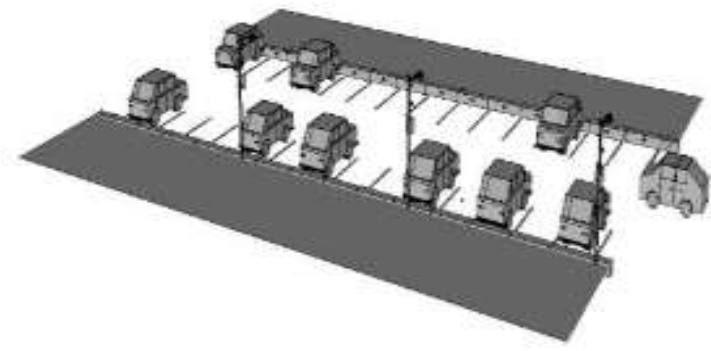

Figure 5

Overview Parking area

System Testing scenario as follows:

* 3 cameras installed on street lighting.

* Testing in day and night.

\section{EXPERIMENT RESULT}

Figure 6,7 , and 8 show the result of experiment.

\section{On-site Experiment}

This research experiment conducted to evaluate the smart camera system effectiveness, to monitor the area parking. Three cameras dispatched at different places to get more than one evaluation.

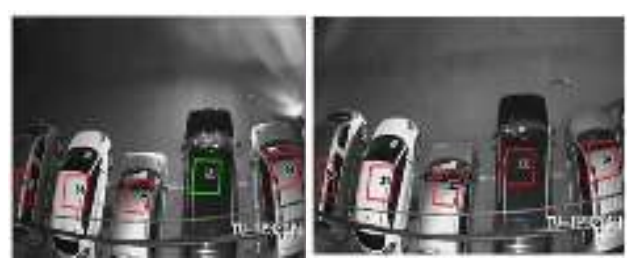

Figure 6.

Smart camera 1: running experiment



Figure 7.

Smart Camera 2: running experiment

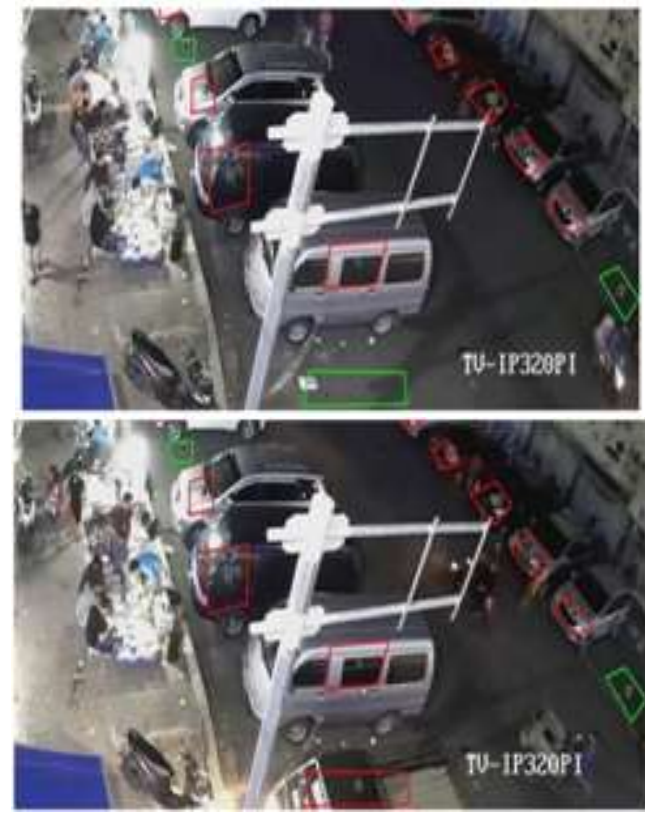

Figure 8

Smart Camera 3: running experiment

The result from 3 location with different kind of camera and conducted alongside time random. The picture before apply the adaptive brightness thresholding show that some part still has flaw, and after show the upgrade result with small flawless. Green box refers to the empty parking lot and red box refer to the non-empty parking lot.

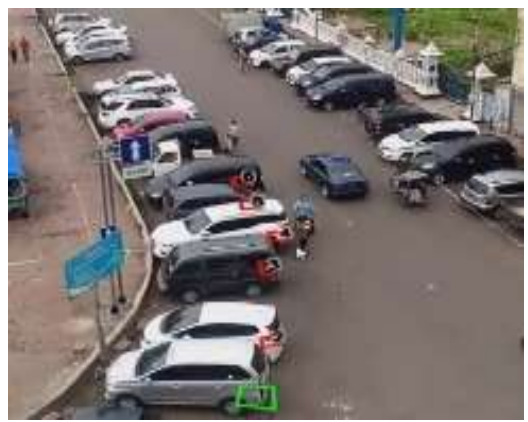

Figure 9.

On day-time experiment

Figure 9 show that on the daytime with different angle view from camera; 5 parking lot detected as non-empty, but 1 parking lot has false information as an empty parking lot. This error occurs because of the nonaccurate box setting, it's difficult for the system to detect the edge of the object. 


\section{Information System}

Information system is another part of the system to show the result of this experiment. Data from the camera send to the server, server-side application process the data and show the information to the web and mobile application.
Figure 10 shows the web application with the feature:

- Vehicle estimation inside the parking area.

- Parking attendant on duty.

- Recapitulation of the vehicle number filter by the day / week / month / year.

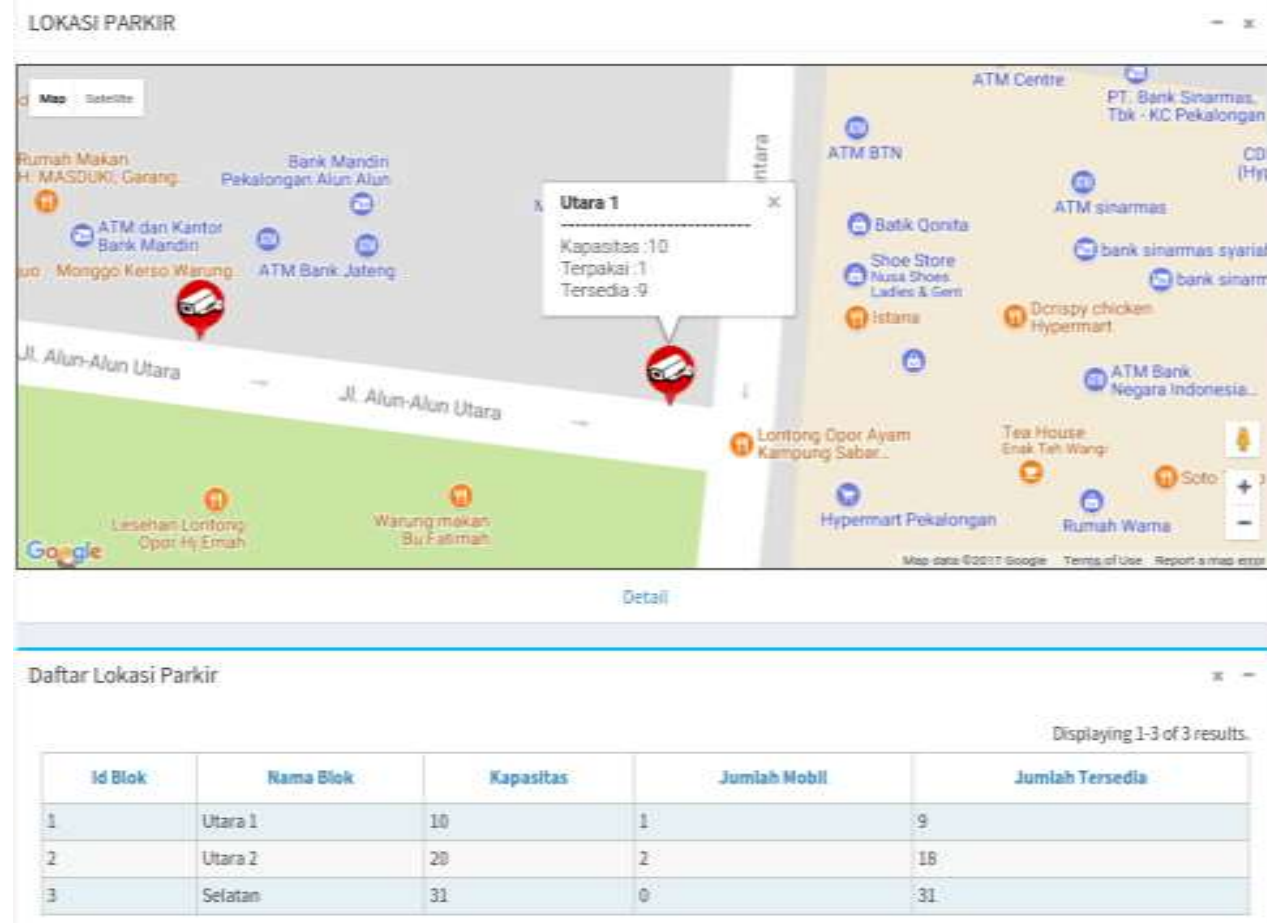

Figure 10.

Web app parking information

Figure 11 show the mobile application parking information.

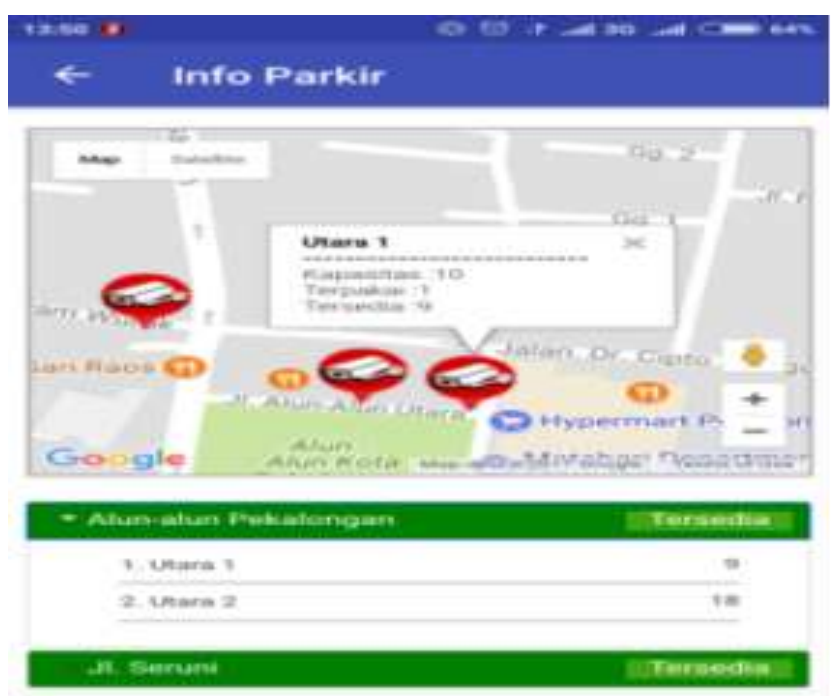

Figure 11.

Mobile app parking information 
Mobile application feature consists:

* The number of parking lot.

* Map-based parking area.

\section{CONCLUSSION}

Based on the experiment result, this research conclusion: Experiment result show the better result, with error related to the object non-vehicle that detected as vehicle. The testing results shows an error arises when the colour of the parking vehicle is the same as colour of the road (asphalt colour) so system could be improved. Initial setting for position of camera configuration is an important factor to create parking virtual boundary. Prototype for monitoring and management parking system are implemented to the four and more wheel's vehicle, thus it's needed another approach if this system implemented to the motorcycle case.

\section{ACKNOWLEDGEMENT}

Thanks to PTSPT, BPPT that fully support this research related to the technical support and research funding.

\section{REFERENCES}

1. Castro, M. R., Teixeira, M. A., Nakamura, L. H., and Meneguette, R. I. A Prototype of a Car Parking Management Service based on Wireless Sensor Networks for ITS. International Robotics \& Automation Journal, Vol. 2 - No. 3 (2017).

2. Shaikh, F. I., Jadhav, P. N., Bandarkar, S. P., Kulkarni, O. P. and Shardoor, N. B. Smart Parking System Based on Embedded System and Sensor Network. International Journal of Computer Applications, Vol. 140 - No.12, 45-51 (2016).

3. Moses, N., and Chincholkar, Y. D. IJARCCE Smart Parking System for Monitoring Vacant Parking. International Journal of Advanced Research in Computer and Communication Engineering, Vol. 5 No. 6, 717-720 (2016).
4. Gupta, S., and Ghosh Mazumdar, S. Sobel Edge Detection Algorithm. International Journal of Computer Science and Management Research, Vol. 2 - No. 2, 1578-1583 (2013).

5. Banerjee, S., Journal, I., and Science, C. Implementation of Image Processing in Real Time Car. Indian Journal of Computer Science and Engineering, Vol. 2 - No. 1, 11-15 (2011).

6. Rashid, M. M, Musa, A., Rahman, M.A., Farahana, N., and Farhana, A. Automatic Parking Management System and Parking Fee Collection Based on Number Plate Recognition. International Journal of Machine Learning and Computing, Vol. 2 - No. 2, 93-98 (2012). [Online].

7. Goutham, J. and Chaitra, B. R. Cloud-Based Cost-Efficient Smart Parking System. International Journal of Advances in Computer Science and Cloud Computing, Vol. 5, Issue1, 16-19 (2017).

8. Ahmed, M. R., and Jeaunita, T. C. J. IoT Based Cost Efficient Smart eParking System. International Journal of Advanced Research in Electrical, Electronics and Instrumentation Engineering, Vol. 5, Issue-11, 86468655 (2016).

9. Alshamsi, H., \& Këpuska, V. Smart Car Parking System. International Journal of Science and Technology, 5, 390-395 (2016).

10. Therib, M., Al-Zahra, A., Falah, M., and Hussam, Z. Design and Implementation of Smart Car Parking System. Thesis for Bachelor of Science in Computer Techniques Engineering, Al-Mustaqbal University College, (2016) 
(halaman ini sengaja dikosongkan) 